\title{
The effect of bisphosphonates on gene expression: GAPDH as a housekeeping or a new target gene?
}

\author{
Maria Teresa Valenti ${ }^{1}$, Francesco Bertoldo ${ }^{1}$, Luca Dalle Carbonare*1, \\ Giuseppe Azzarello² ${ }^{2}$ Sonia Zenari ${ }^{1}$, Mirko Zanatta1 ${ }^{1}$, Elena Balducci², \\ Orazio Vinante ${ }^{2}$ and Vincenzo Lo Cascio ${ }^{1}$
}

\begin{abstract}
Address: ${ }^{1}$ Medicina Interna D, Department of Biomedical and Surgical Sciences, University of Verona, Italy and ${ }^{2}$ Department of Oncology and Hematologic Oncology - Noale Hospital, Italy

Email: Maria Teresa Valenti - valenti.lab.oncnoale@inwind.it; Francesco Bertoldo - francesco.bertoldo@univr.it; Luca Dalle Carbonare* - luca.dallecarbonare@univr.it; Giuseppe Azzarello - azzarello.med.oncnoale@inwind.it; Sonia Zenari - sonieka@libero.it; Mirko Zanatta - mirkozanatta@libero.it; Elena Balducci - balducci.lab.oncnoale@inwind.it; Orazio Vinante - Vinante.med.oncnoale@inwind.it; Vincenzo Lo Cascio - vincenzo.locascio@univr.it

* Corresponding author
\end{abstract}

Published: 03 March 2006

BMC Cancer 2006, 6:49 doi:10.1 186/147/-2407-6-49
Received: II October 2005

Accepted: 03 March 2006

This article is available from: http://www.biomedcentral.com/147I-2407/6/49

(C) 2006 Valenti et al; licensee BioMed Central Ltd.

This is an Open Access article distributed under the terms of the Creative Commons Attribution License (http://creativecommons.org/licenses/by/2.0), which permits unrestricted use, distribution, and reproduction in any medium, provided the original work is properly cited.

\begin{abstract}
Background: RT-PCR has been widely used for the analysis of gene expression in many systems, including tumor samples. GAPDH (Glyceraldehyde-3-phosphate dehydrogenase) has been frequently considered as a constitutive housekeeping gene and used to normalize changes in specific gene expression. However, GAPDH has been shown to be up-regulated in many cancers and down-regulated by chemotherapic drugs. Bisphosphonates, potent inhibitors of bone resorption, have recently shown a direct and indirect antitumor effect in vitro and in animal models. They exert their effects mainly by inhibiting the mevalonate pathway but also by modulating the expression of many genes not only in osteoclasts but also in cancer cells.
\end{abstract}

Methods: We evaluated GAPDH gene expression by real time RT PCR in breast (MCF-7 and T47D) and prostate (PC3 and DU-I45) cancer cell lines treated with amino and non-amino bisphosphonates.

Results: Our results showed that amino-bisphosphonates significantly decrease in a dosedependent manner the expression of GAPDH gene.

Conclusion: Therefore, GAPDH is inaccurate to normalize mRNA levels in studies investigating the effect of bisphosphonates on gene expression and it should be avoided. On the other hand, this gene could be considered a potential target to observe the effects of bisphosphonates on cancer cells.

\section{Background}

GAPDH (Glyceraldehyde-3-phosphate dehydrogenase) is well known for its glycolytic function of converting DGlyceraldeide-3-phosphate to 1,3-bisphosphoglycerate and it has been commonly considered as a constitutive housekeeping gene. It is widely used as a control RNA in Northern Blotting and in RT-PCR analysis and recently in real time RT-PCR. 
In some experimental systems its expression is constant at different times and after experimental manipulation [1]. In breast cancer cells treated with endoxifen GAPDH was used to normalize the expression data of the progesterone receptor mRNA [2]. In addition, GAPDH was the best control gene in the apoptosis pattern on the myeloid cell lines incubated with Camptothecin investigated by real time RT-PCR [3].

However, there is overwhelming evidence suggesting that its use as an internal standard is inappropriate [4]. Growth hormone, oxidative stress and the tumour suppressor TP53 have all been shown to activate its transcription, which can also be induced in endothelial cells [5]. Conversely, retinoic acid down-regulates GAPDH transcription in adipocytes [6]. Furthermore, it has been observed that GAPDH mRNA expression was not normal in some tumour samples and its distribution exhibited a wide range of values. GAPDH mRNA was over-expressed in the poorly differentiated BT-20 cell line and the treatment of these cells with 1,25-dihydroxyvitamin D3 $(1,25-$ $\left.(\mathrm{OH})_{2} \mathrm{D} 3\right)$ stimulated GAPDH mRNA expression in a dose- and time-dependent manner [7]. A significant increase in GAPDH expression was observed when MCF7 cells were stimulated with several factors as oestradiol, insulin growth factor 1 (IGF1) and basic fibroblast growth factor (bFGF) [8]. In addition, it has been observed that the GAPDH was up-regulated in rat hepatomas [9], malignant murine cell lines [10] and human prostate carcinoma [11].

GAPDH was also widely utilized as a control gene in studies conducted in the last decade to elucidate by RT-PCR the cellular effects of bisphosphonates, not only on osteoclasts or osteoblasts, but also on tumor cells $[12,13]$.

Bisphosphonates (BPs), synthetic analogs of pyrophosphate, are potent inhibitors of bone resorption through the inhibition of osteoclast activity and recruitment $[14,15]$. They are used in many metabolic bone diseases. Furthermore, recent studies have demonstrated that BPs have an anti-tumour activity too, as highligthed by a reduced skeletal tumour burden and a slower progression of bone lesions in animal models [16]. BPs inhibit proliferation, cell adhesion to non-mineralised bone matrices and induce the apoptosis of a variety of human tumour cell lines in vitro [17-20]. Most of the BPs pharmacological activities have been related to inhibition of the mevalonate pathway [21], but the modulation of relative expression of a variety of genes implicated in osteoclast, osteoblast and tumour cell function has recently been reported [22-24]. On this basis and since the GAPDH is commonly used as housekeeping gene, also in studies using bisphosphonates, and since it is upregulated in many cancer $(7-9,11)$ and downregulated by chemother- apic drugs (6), we assessed the effects, if any, of some bisphosphonates commonly used in cancer bone disease on GAPH gene expression in breast and prostate cancer cell lines.

\section{Methods \\ Cells}

Human prostatic cancer cell lines (PC-3 and DU-145) and human breast cancer cell lines (MCF-7 and T-47D) were purchased from the American Type Culture Collection (ATTC Rockville, MD, USA). The cells were maintained at $37^{\circ} \mathrm{C}$ in a humidified atmosphere with $5 \% \mathrm{CO}_{2}$ in DMEM-F12 containing $2 \mathrm{mM}$ L glutamine, $10 \%$ fetal bovine serum, $100 \mathrm{U} / \mathrm{ml}$ streptomycin and $100 \mu \mathrm{g} / \mathrm{ml}$ penicillin.

\section{Bisphosphonates studies}

Alendronate (4-amino-1-hydroxybutilene-1,1-bisphosphonate), clodronate (tetrahydrate dichloromethylenebisphosphonate, disodium), and pamidronate (3-amino1-hydroxypropylidene-bisphosphonate acid, $2 \mathrm{Na}$ ) were purchased from Calbiochem. Zoledronate (1-hydroxy2,1-imidazol-1-yl-ethylidene bisphosphonic acid) was kindly provided by Novartis. The neutralized sodium salts of BPs were dissolved in sterile double distilled $\mathrm{H}_{2} \mathrm{O}$ at a final concentration of $100 \mathrm{mM}$. Stock solutions were aliquoted and kept at $-20^{\circ} \mathrm{C}$ for long term storage.

Cells from $80 \%$ confluent cultures were washed with PBS and treated with trypsin/EDTA. Cells were plated at $1 \times$ $10^{6}$ in $25 \mathrm{~cm}^{2}$ flask and incubated for $24 \mathrm{~h}$ at $37^{\circ} \mathrm{C}$, allowing adhesion of the cells to the new culture plates. Cells were treated for $48 \mathrm{~h}$ with BPs concentrations of 100, 50, and $10 \mu \mathrm{M}$ in DMEM/F12 containing 5\% FBS. For each concentration three separate flasks were treated.

\section{Total RNA extraction}

Before RNA extraction apoptotic cells were cut out by harvesting medium for each fask. Adherent cells were washed twice with PBS and trypsinized; the cell pellets were collected by centrifugation at $1000 \mathrm{~g}$ for $10 \mathrm{~min}$ at $4{ }^{\circ} \mathrm{C}$. Total RNA was extracted from each cell culture flask using the RNAeasy minikit (Quiagen) with DNAse I treatment. The amount of extracted RNA was quantified by measuring the absorbance at $260 \mathrm{~nm}$. The purity of the RNA was checked by measuring the ratio of the absorbance at 260 and $280 \mathrm{~nm}$, where a ratio ranging from $1.8-2.0$ was taken to be pure. The absence of degradation of the RNA was confirmed by RNA electrophoresis on a $1.5 \%$ agarose gel containing ethidium bromide.

\section{Reverse transcription}

First-strand cDNA was generated from $1 \mu \mathrm{g}$ of each flask using the High-Capacity cDNA Archive Kit, with random hexamers, (Applied Biosystems PE) according to the man- 
ufacturer's protocol. RT product was aliquoted in equal volumes and stored at $-80^{\circ} \mathrm{C}$.

\section{Real time PCR}

PCR was performed in a total volume of $50 \mu \mathrm{l}$ containing 1x Taqman Universal PCR Master mix, no AmpErase UNG and $5 \mu \mathrm{l}$ of cDNA; pre-designed, Gene-specific primers and probe sets for each gene (GAPDH; Hs99999905-m1) (Beta 2 microglobulin (B2M); Hs99999907) were obtained from Assay-on-Demand Gene Expression Products (Applied Biosystems). The real time amplifications included 10 minutes at $95^{\circ} \mathrm{C}$ (AmpliTaq Gold activation), followed by 40 cycles at $95^{\circ} \mathrm{C}$ for 15 seconds and at $60^{\circ} \mathrm{C}$ for 1 minute. As previously reported, the Ct value correlates to the starting quantity of target mRNA [25]. PCR efficiencies were calculated with a relative standard curve, derived from a four cDNA dilution series in triplicate and gave regression coefficients greater than 0.98 and efficiencies greater than $96 \%$. To normalize the GAPDH mRNA expression from sample to sample in RNA input, quality and reverse transcriptase efficiency, we amplified the housekeeping gene $\mathrm{B} 2 \mathrm{M}$. The $\mathrm{B} 2 \mathrm{M}$ endogenous/internal control gene was abundant and remained constant, in proportion to total RNA, among the samples. The GAPDH and $\mathrm{B} 2 \mathrm{M}$ ratio represented the normalized GAPDH (the GAPDH/B2M ratio).

\section{Standard curves}

The relative standard curves were obtained using the GAPDH and B2M gene primers and probes in singleplex, amplified with 10, 20, 40 and 80 ng of total RNA, respectively for each control cell line. Each sample was run in triplicate. The curves obtained for each cell line showed a linear relationship between RNA concentration and the $\mathrm{Ct}$ value of PCR real time for both GAPDH gene and B2M gene.

We selected the $\Delta \mathrm{Rn}$ in the exponential phase of amplification plots to determine the $\mathrm{Ct}$ values and to obtain the linearity of calibration curves.

\section{Statistical analysis}

Results are expressed as mean \pm S.E.M. Student's paired ttest was used to evaluate differences between the sample of interest and its respective control. The Wilcoxon test was used for nonparametric data. For analysis of dose responses, multiple measurement ANOVA followed by Newman-Keuls as a post-hoc analysis was performed. A probability value $<0.05$ was considered statistically significant. Analyses were applied to experiments carried out at least three times. Statistical analyses were performed using Statgraphics Plus, version 5 (Manugistics, Inc, Rockville, $\mathrm{MD})$.

\section{Results}

Our results showed that BPs decrease, in a dose-dependent manner, the expression of the GAPDH gene.

In PC-3 cells at $10 \mu \mathrm{M}$, the lowest dose tested, only Zoledronate significantly lowered the gene expression with respect to control ( $\mathrm{p}<0.001$ ), whereas Alendronate and Pamidronate significantly down-regulate GAPDH gene expression at a concentration of $50(\mathrm{p}<0.001$ and $\mathrm{p}<$ 0.005 , respectively) and $100 \mu \mathrm{M}(\mathrm{p}<0.001)$. Comparing the effects among the different BPs, Zoledronate induced a greater inhibition of GAPDH gene expression at concentrations of $10 \mu \mathrm{M}$ with respect to the Pamidronate ( $<<$ $0.01)$ and Alendronate $(\mathrm{p}<0.05)$. Zoledronate lowered significantly the GAPDH gene expression at a concentration of $50 \mu \mathrm{M}$ with respect to the Pamidronate $(\mathrm{p}<0.05)$. At a concentration of $100 \mu \mathrm{M}$, amino-bisphosphonates showed a similar inhibition of GAPDH gene expression (Figure 1A).

Alendronate and Zoledronate induced a significant downregulation at $10 \mu \mathrm{M}$ with respect to control ( $\mathrm{p}<0.05$ and $\mathrm{p}<0.001$, respectively) in DU-145 cell line. At the doses of 50 and $100 \mu \mathrm{M}$ all the amino-BPs tested significantly lowered GAPDH gene expression with respect to control $(p<0.001)$. Zoledronate at concentrations of 10, 50 and $100 \mu \mathrm{M}$ significantly down-regulated GAPDH gene expression with respect to Pamidronate and Alendronate at the same doses $(\mathrm{p}<0.001)$. (Figure 1B).

In the T-47D cells Alendronate and Pamidronate significantly lowered GAPDH gene expression with respect to control in a dose dependent manner with all the doses tested $(\mathrm{p}<0.001)$, whereas Clodronate down-regulated expression only at $100 \mu \mathrm{M}(\mathrm{p}<0.05)$ (Figure 2A). However, Alendronate and Pamidronate at 10,50 and $100 \mu \mathrm{M}$ significantly decreased GAPDH gene expression with respect to all the doses of Clodronate ( $p<0.001)$. At 10 $\mu \mathrm{M}$ Alendronate significantly down-regulated the gene expression with respect to Pamidronate at the corresponding concentration $(\mathrm{p}<0.05)$.

We found similar results in MCF-7 cells. With all the doses Alendronate and Pamidronate significantly down-regulated GAPDH gene expression with respect to control in a dose dependent manner $(\mathrm{p}<0.001)$, whereas Clodronate decreased, even if not significantly, this expression only at $100 \mu \mathrm{M}$. Alendronate and Pamidronate significantly down-regulated the GAPDH gene expression with respect to Clodronate at the same concentrations $(\mathrm{p}<0.001)$ (Figure $2 \mathrm{~B})$.

\section{Discussion}

In the present study, we have quantified by real time RT PCR the effect of the BPs on the expression of the GAPDH 

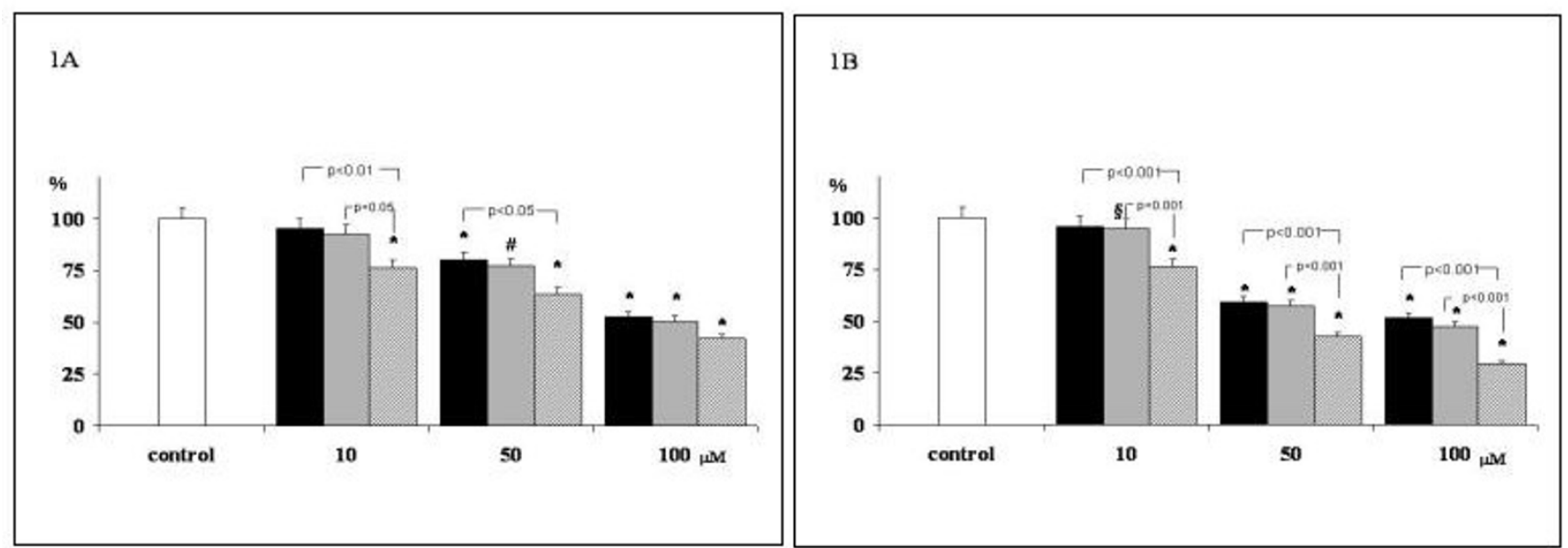

\section{Figure I}

Normalized GAPDH gene expression data in PC-3 (Fig. IA) and in DU-I45 (Fig. IB) prostate cancer cells. Control was used as calibrator. Fig. IA: In PC-3 and DU-I45 cells amino-bisphosphonates ( $\square$ Pamidronate, $\square$ Alendronate, $\$$ Zoledronate) lowered in a dose-dependent manner the GAPDH gene expression. * $\mathrm{p}<0.00$ I vs control; \# $\mathrm{p}<0.005$ vs control; $\$ \mathrm{p}<0.05$ vs control.

gene in prostate cancer cells (PC-3; DU-145) and in breast cancer cells (MCF-7; T-47D). Our results show a significant dose-dependent down-regulation of GAPDH gene expression after treatment of different cancer cell lines with different amino-BPs. Our results also indicate that Zoledronate was the most powerful bisphosphonate, whereas Clodronate, a non-amino bisphosphonate, exerted significant effect on GAPDH gene expression only at the highest concentration tested. This is, to our knowledge, the first report on the effects of BPs on GAPDH gene expression.
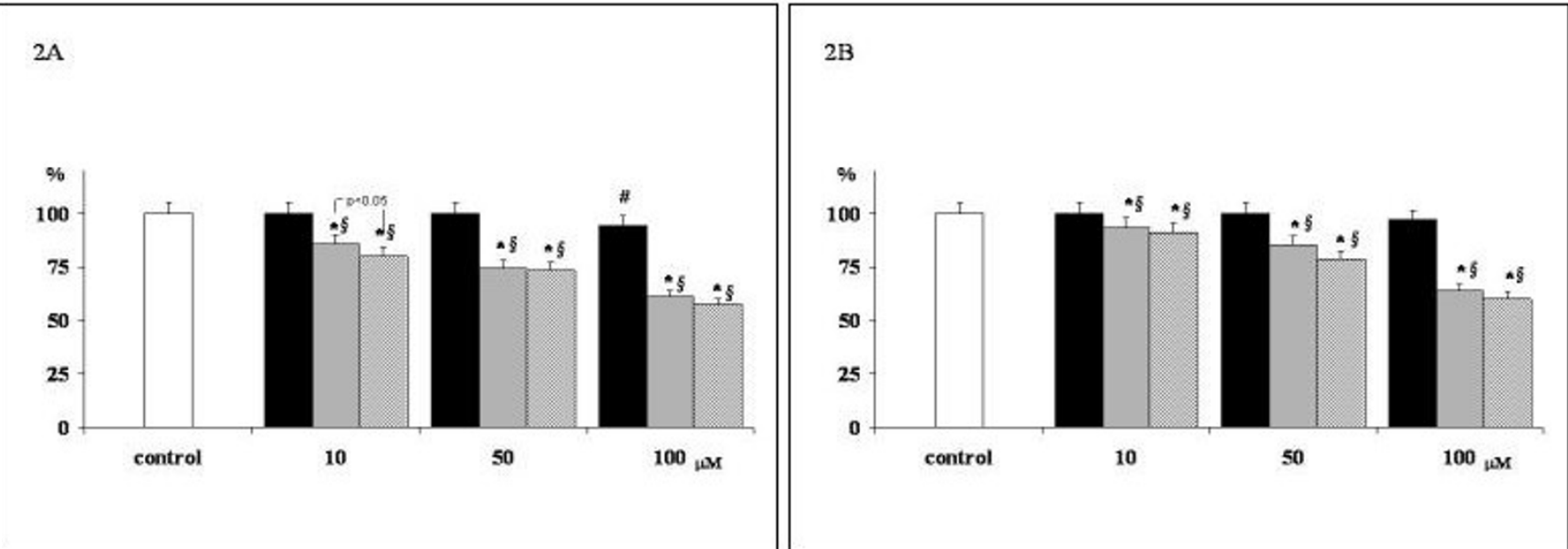

\section{Figure 2}

Normalized GAPDH gene expression data in T-47D (Fig.2A) and MCF-7 (Fig.2B) breast cancer cells. Control was used as calibrator. Amino-BPs ( $\square$ Alendronate, $N$ Pamidronate) significantly down-regulated the GAPDH expression with respect to control in a dose-dependent manner, whereas Non-Amino-BPs ( Clodronate) down-regulated this expression at $100 \mu M$ only in T-47D breast cancer cell line. ${ }^{*} \mathrm{p}<0.00$ I vs control; \# $\mathrm{p}<0.05$ vs control; $\S \mathrm{p}<0.00$ I vs Clodronate 
Some studies using GAPDH as a housekeeping gene showed the up-regulation of the expression of collagenase 3 [12], sialoprotein [26], TNF- $\alpha$ [27] TNF- $\alpha$ Converting Enzyme [28], osteoprotegerin [22], ALP and OC genes [29], by BPs. On the other hand, RANKL [30,31], PTHrp [32], osteopontin [33], Calcitonin receptor [29] were down-regulated. We may speculate that there could be two main reasons for the wide use of GAPDH gene as a housekeeping gene. The first being a general agreement that BPs act almost exclusively through the inhibition of mevalonate pathway, as confirmed by the evidence that $\mathrm{GGOH}$ and $\mathrm{FOH}$, final products of mevalonate pathway, can completely reverse BPs effects [34]. However, some authors have documented effects independent from mevalonate pathway inhibition [35]. The second reason is that the large use of semiquantitative RT-PCR obscures the quantitative effects, such as the action of BPs on the expression of a single gene (also in the case of a control gene).

Our original observation has some interesting implications. First of all, as GAPDH mRNA expression is downregulated in a dose-dependent manner by amino-BPs and we could speculate that every time a dose-dependent gene up-regulation is reported, it could be the effect of the concomitant down-regulation of the control gene expression, or it could be, at least, overestimated. On the contrary, the down-regulation of the housekeeping gene could obscure the detection of a possible specific gene down-regulation. A further consideration is that GAPDH could be considered as a novel target gene for BPs, showing not only a sensitive down-regulation but also reflecting the well accepted rank of relative in vitro and in vivo potency between amino and non-amino BPs and within aminoBPs [21].

It was shown that GAPDH is able to constitute a ternary complex with DNA and saframycin-related compound that induces a toxic response in cells. The demonstration that a specific binding interaction occurs between GAPDH, duplex DNA, and several members of the saframycin class of antiproliferative agents suggests GAPDH as a potential target for chemotherapeutic intervention [36]. GAPDH has a complex and evolving role in the nucleus, where it seems to act as a monomer [37]. GAPDH has been identified as a component of a multiprotein nuclear complex that recognized oligonucleotides incorporating the antileukemic agent thioguanosine [38], although GAPDH has not been shown to bind directly to the thioguanosine-modified DNA. Monomeric GAPDH has also been found as the main component of a multiprotein nuclear complex involved in transcriptional coactivation of the histone $2 \mathrm{~B}$ promoter, required for $\mathrm{S}$ phase progression in the cell cycle [39].
These data raise the possibility that, at least in part, the direct effect of amino-BPs on cancer cells could be mediated by GAPDH down-regulation. Interestingly, by utilizing real time PCR, GAPDH mRNA has been downregulated by many antineoplastic drugs $[36,40]$ and it has been related to apoptosis [41].

This study was designed to investigate the possible effects of BPs on GAPDH mRNA expression, and to explore the reliability of GAPDH as a housekeeping gene in real time RT-PCR analysis. Therefore, the data obtained do not allow the definition of a specific mechanism of action of amino-BPs through GAPDH down-regulation and we can only speculate that BPs could affect vitality in cancer cells in other ways apart from through the inhibition of the mevalonate pathway, i.e. through the down-regulation of GAPDH.

\section{Conclusion}

The use of GAPDH as a control gene, in particular in studies investigating the effects of BPs on bone or cancer cells, seems to be inappropriate and RT-PCR data on the effects of BPs in cancer cells should be reviewed by a quantitative approach using real time PCR, with a different housekeeping gene.

\section{Competing interests}

The authors of this manuscript dclare that they have no financial, political, religious, academic, intellectual, commercial or any other competing interests.

\section{Authors' contributions}

MTV participated in the design of the study and carried out the molecular assays

FB participated in the design of the study and contributed to draft the manuscript

LDC participated in the design of the study and performed the statistical analysis

GA helped to perform the statistical analysis and participated to draft the manuscript

SZ carried out the molecular assays

$\mathrm{MZ}$ carried out the molecular assays

EB carried out the molecular assays and drafted the manuscript

OV participated in the design of the study and contributed to draft the manuscript 
VLC conceived the study and coordinated to draft the manuscript

\section{All authors read and approved the final manuscript.}

\section{References}

I. Edwards DR, Denhardt DT: A study of mitochondrial and nuclear transcription with cloned cDNA probes. Changes in the relative abundance of mitochondrial transcripts after stimulation of quiescent mouse fibroblasts. Exp Cell Res 1985, 157:| 127-| 43.

2. Lim YC, Desta Z, Flockhart DA, Skaar TC: Endoxifen has antiestrogenic effects in breast cancer cells with potency similar to 4-hydroxy-tamoxifen. Cancer Chemother Pharmacol 2005, 55:47I-8.

3. Ullmannova $\mathrm{V}$, Haskovec $\mathrm{C}$ : The use of housekeeping genes (HKG) as an internal control in the detection of gene expression by quantitative real time RT-PCR. Folia Biol 2003, 49:2II-6.

4. Oliveira JG, Prados RZ, Guedes AC, Ferreira PC, Kroon EG: The housekeeping gene glyceraldehyde-3-phosphate dehydrogenase is inappropriate as internal control in comparative studies between skin tissue and cultured skin fibroblasts using Northern blot analysis. Arch Dermatol Res 1999, 291:659-661.

5. Bustin SA: Absolute quantification of mRNA using real-time reverse transcription polymerase chain reaction assays. J Mol Endocrinol 2000, 25:169-193.

6. Barroso I, Benito B, Garci-Jimenez C, Hernandez A, Obregon MJ, Santisteban P: Norepinephrine, tri-iodothyronine and insulin upregulate glyceraldehyde-3-phosphate dehydrogenase mRNA during Brown adipocyte differentiation. Eur J Endocrinol 1999, 141:169-179.

7. Desprez PY, Poujol D, Saez S: Glyceraldehyde-3-phosphate dehydrogenase gene expression in two malignant human mammary epithelial cell lines: BT-20 and MCF-7 regulation of gene expression by 1,25 dihydroxyvitamin D3 (I,25(OH)2D3). Cancer Lett 1992, 64:219-244.

8. Revillion F, Pawlowski V, Hornez L, Peyrat JP: Glyceraldehyde-3phosphate dehydrogenase gene expression in human breast cancer. Eur J Cancer 2000, 36:1038-1042.

9. Chang TJ, Juan CC, Yin PH, Chi CW, Tsay HJ: Up-regulation of beta-actin, cyclophilin and GAPDH in NISI rat hepatoma. Oncol Rep 1998, 5:469-471.

10. Bhatia P, Taylor WR, Greenberg AH, Wright JA: Comparison of glyceraldehyde-3-phosphate dehydrogenase and 28S-ribosomal RNA gene expression as RNA loading controls for northern blot analysis of cell lines of varying malignant potential. Anal Biochem 1994, 216:223-226.

II. Ripple MO, Wilding G: Alteration of glyceraldehyde-3-phosphate dehydrogenase activity and messenger RNA content by androgen in human prostate carcinoma cells. Cancer Res 1995, 55:4234-4236.

12. Varghese $\mathrm{S}$, Canalis E: Alendronate stimulates Collagenase 3 expression in osteoblasts by posttranscriptional mechanisms. J Bone Miner Res 2000, 15:2345-235I.

13. Dalle Carbonare L, Valenti MT, Azzarello G, Balducci E, Crepaldi G, Realdi G, Vinante O, Giannini S: Bisphosphonates decrease telomerase activity and hTERT expression in MCF-7 breast cancer cells. Mol Cell Endocrinol 2005, 240:23-3I.

14. Fleish $\mathrm{H}$ : Experimental basis for the use of bisphosphonates in Paget's disease of bone. Clin Othop 1987, 21 7:72-78.

15. Flanagan AM, Chambers TJ: Inhibition of bone resorption by bisphosphonate, osteoclast, and bone. Calcif Tissue Int 1991, 49:407-4I5

16. Lee MV, Fong EM, Singer FR, Guenette RS: Bisphosphonates treatment inhibits the growth of prostate cancer cells. Cancer Res 200I, 6I:2602-2608.

17. Boisser S, Magnetto S, Frapport L, Cuzin B, Ebetino FH, Delmas PD, Clezardin P: Bisphosphonates inhibit prostate and breast carcinoma cell adhesion to unmineralized bone extracellular matrices. Cancer Res 1997, 57:3890-3894.
18. Brown JE, Neville-Webbe H, Coleman RE: The role of bisphosphonates in breast and prostate cancers. Endocr Relat Cancer 2004, I I:207-24.

19. Shipman CM, Rogers MJ, Apperley JF, Russell RG, Croucher PI: Bisphosphonates induce apoptosis in human myeloma cell lines: a novel anti-tumour activity. $\mathrm{Br} J$ Haematol 1997, 98:665-72.

20. Tassone P, Tagliaferri P, Viscomi C, Palmieri C, Caraglia M, D'Alessandro A, Galea E, Goel A, Abbruzzese A, Boland CR, Venuta S: Zoledronic acid induces antiproliferative and apoptotic effects in human pancreatic cancer cells in vitro. $\mathrm{Br} J$ Cancer 2003, 88: | $97|-| 978$.

21. Rogers MJ, Gordon S, Benford HL, Coxon FP, Luckman SP, Monkkonen J, Frith JC: Cellular and molecular mechanism of action of bisphosphonates. Cancer 2000, 88:296I-297.

22. Viereck V, Emons G, Lauck V, Frosch KH, Blaschke S, Grundker C, Hofbauer LC: Bisphosphonates Pamidronate and Zoledronic acid Stimulates osteoprotegerin production by primary human osteoblasts. Biochem Biophys Res Commun 2002, 291:680-686.

23. Green JR: Bisphosphonates: preclinical review. Oncologist 2004, 9:3-13.

24. Fromigue $O$, Lagneaux L, Body IJ: Bisphosphonates induce breast cancer cell death in vitro. J Bone Miner Res 2000, 15:22II-222I.

25. Heid CA, Stevens J, Livak KJ, Williams PM: Real time quantitative PCR. Genome Res 1996, 6:986-994.

26. Chaplet M, Detry C, Deroanne C, Fisher LW, Castronovo V, Bellahcene $A$ : Zoledronic acid up-regulates bone sialoprotein expression in osteoblastic cells through Rho GTPase inhibition. Biochemical J 2004, 384:59I-598.

27. Takagi K, Takagi M, Kanangat S, Warrington KJ, Shigemitsu H, Postlethwaite AE: Modulation of TNF-alpha gene expression by IFN-gamma and Pamidronate in murine macrophages: regulation by STATI-dependent pathways. J Immunol 2005, 174: $1801-1810$

28. Pan B, Farrugia AN, To LB, Findlay DM, Green J, Lynch K, Zannettino $A B$ : The nitrogen-containing bisphosphonate, zoledronic acid, influences RANKL expression in human osteoblast-like cells by activing TNF-alpha converting enzyme (TACE). J Bone Miner Res 2004, 19:147-154.

29. Myoung H, Park JY, Choung PH: Effects of a bisphosphonate on the expression of bone specific genes after autogenous free bone grafting in rats. J Periodontal Res 200I, 36:244-25I.

30. Kim YH, Kim GS, Jeong-Hwa B: Inhibitory action of bisphosphonates on bone resorption does not involve the regulation of RANKL and OPG expression. Exp Mol Med 2002, 34:145-I5I.

31. Nishida S, Tsubaki M, Hoshino M, Namimatsu A, Uji H, Yoshioka S, Tanimori Y, Yanae M, Iwaki M, Irimajiri K: Nitrogen-containing bisphosphonates, YM529/ONO-5920 (a novel minodronic acid), inhibits RANKL expression in a cultured bone marrow stromal cell line ST2. Biochem Biophys Res Commun 2005, 328:91-97.

32. Gomez-Garcia L, Esbrit P, Carreno L, Sabando P, Garcia-Flores M, Martinez ME: Alendronate interacts with the inhibitory effect of $\mathrm{I}, 25(\mathrm{OH})_{2} \mathrm{D}_{3}$ ) on Parathyroid Hormone-Related Protein Expression in Human osteoblastic cells. J Bone Miner Res 2003, 18:78-87.

33. Yasui T, Fujita K, Sasaki S, Iguchi M, Hirota S, Nomura S, Azuma Y, Ohta T, Kohri K: Alendronate inhibits osteopontin expression enhanced by parathyroid hormone-related peptide (PTHrp) in the rat kidney. Urol Res 1998, 26:355-360.

34. Neville-Webbe HL, Rostami-Hodjegan A, Evans CA, Coleman RE, Holen I: Sequence and schedule-Dependent enhancement of zoledronic acid induced apoptosis by doxorubicin in breast and prostate cancer cells. Int J Cancer 2005, I I 3:364-37I.

35. Van Beek ER, Cohen LH, Leroy IM, Ebetino FH, Lowik CW, Papapoulos SE: Differentiating the mechanisms of antiresorptive action of nitrogen containing bisphosphonates. Bone 2003, 33:805-II.

36. Xing C, LaPorte JR, Barbay JK, Myers AG: Identification of GAPDH as a protein target of the saframycin antiproliferative agents. Proc Natl Acad Sci USA 2004, I 1 I:5862-5866.

37. Sirover MA: New insights into an old protein: the functional diversity of mammalian glyceraldehyde-3-phosphate dehydrogenase. Biochim Biophys Acta 1999, 1432:159-184. 
38. Krynetski EY, Krynetskaia NF, Gallo AE, Murti KG, Evans WE: A novel protein complex distinct from mismatch repair binds thioguanylated DNA. Mol Pharmacol 200I, 59:367-74.

39. Zheng L, Roeder RG, Luo Y: S phase activation of the histone H2B promoter by OCA-S, a coactivator complex that contains GAPDH as a key component. Cell 2003, I | 4:255-266.

40. Appelskog IB, Ammerpohl O, Svechnikova IG, Lui WO, Almqvist PM, Ekstrom TJ: Histone deacetylase inhibitor 4-phenylbutyrate suppresses GAPDH mRNA Expression in glioma cells. Int J Oncol 2004, 24:14|9-25.

4I. Tatton WG, Chalmers-Redman RM, Elstner M, Leesch W, Jagodzinski FB, Stupak DP, Sugrue MM, Tatton NA: Glyceraldehyde-3-phosphate dehydrogenase in neurodegeneration and apoptosis signalling. J Neural Transm 2000, 60:77-100.

\section{Pre-publication history}

The pre-publication history for this paper can be accessed here:

http://www.biomedcentral.com/1471-2407/6/49/prepub

Publish with Bio Med Central and every scientist can read your work free of charge

"BioMed Central will be the most significant development for disseminating the results of biomedical research in our lifetime. "

Sir Paul Nurse, Cancer Research UK

Your research papers will be:

- available free of charge to the entire biomedical community

- peer reviewed and published immediately upon acceptance

- cited in PubMed and archived on PubMed Central

- yours - you keep the copyright 